\title{
An Interpretation of the Ecofeminism in The Grapes of Wrath
}

\author{
Yan Liu* \\ Canvard College, Beijing Technology and Business University, No. 1 Song Zhuang Nan Lu, Tong Zhou Dist, Beijing, \\ China \\ *Corresponding author. Email: liuyan_662003@163.com
}

\begin{abstract}
The Grapes of Wrath is one of the representative works of American modern novelist John Steinbeck. It is a documentary novel which reflects the social problems in the Great Depression in 1930s. The article, based on the background of bankruptcy, fleeing and struggling of the state farmers in the middle period of economic crisis, as well as the description of the natural environment, shaping of the female characters and the rebuilding the relationship among human beings, expresses the concern to women and idea of constructing the harmonious development of man and nature. This article is to find the relationship between people and nature, people and people by interpretation of The Grapes of Wrath, and writer's deep concern over the fate of the human being, the anger of the destruction of the natural ecosystem, and concern for the future of humanity. This paper explores the practical significance of the Ecofeminism embodied in the modern society, and enable readers to realize that human development is at the cost of the destruction of nature, and to make people be aware of the importance of harmony between man and nature, as well as the importance of protecting the natural environment.
\end{abstract}

Keywords: John Steinbeck, The Grapes of Wrath, Ecofeminism.

\section{INTRODUCTION}

\subsection{The Introduction of the Grapes of Wrath}

The Grapes of Wrath is a landmark of American literature, one that captures the horrors of the Great Depressionas it probes into the very nature of equality and justice in America." [1] This novel was written by John Steinbeck (1902-1968), a modern American novelist, and published in 1939. The novel describes the story of a large number of farmers who went bankrupt and fled for food during the economic panic of the 1930s in the United States, and reflects the thrilling picture of social struggle. It can be regarded as the epic of the modern American farmers and a masterpiece of modern American literature.

This book tells the story of the Joads, a poor family of tenant farmers in Oklahoma who, like thousands of other poor people, had to leave their hometown to make a living due to years of drought and oppression by big Banks and enterprises. On their way west, their grandparents died, and their oldest son Noah and Connie Rivers (the husband of the pregnant Joad daughter, Rose of Sharon) left the family. Led by Ma Joda, the remaining members realized they could only continue, as nothing was left for them in Oklahoma. After experiencing lots of bitterness and sorrow, they finally reached California. Things were not good in California, they were marginalized, expelled and exploited, and had little food to eat, they were also treated unfairly by other gardeners and farmers. In response to the exploitation, former preacher Jim Casy became a labor organizer and tried to recruit for a labor union. The Joda rose up and joined the strike, and Joad's second son, Tom, became an organizer of the agricultural workers' movement. Fearing for his safety, Ma Joad found Tom and sent him away. Tom headed off to fulfill Jim's task of organizing the migrant workers. The novel ended with the Joads' daughter, Rose of Sharon, saved a dying stranger with her own milk. Fortunately, this novel left to the reader is not the despair of poor, but the people who accepted the suffering life and moved on. They had strong awareness to live, and they were also looking forward to hope. 


\subsection{Ecofeminism and Its Development}

Ecoeminism emerged in the third wave of the feminist movement, is the combination of the feminism movement and ecological protection. In 1974, Francoised Eaubonne, the French feminist scholar, first proposed the term in her feminist writing Le Feminisme ou LaMort. In the 1990s, it becomes one of the influential theory movements. Ecofeminism perspective is diverse, but the nature and women are the basic points. The central idea is that there is direct and inherent connection between the rule of nature and female which are both rooted by patriarchy world view. The main power structure of the western culture is the hierarchy of the rule. In this structure, women must obey the interests of men, and nature must succumb to the rule of mechanization and civilized society. While, the target of ecological feminism is committed to building a new moral outlook and social structure. Ecofeminism are generally concerned about the serious destruction of the ecosystem on earth, and they follow the natural ecological harmony. The purpose of them is the ecological protection of natural and social harmony. Ecofeminism think that comparing to men, women are more responsible and hopeful for ending the human ruling the nature, and women can cure the alienation between man and nature.

\section{INTERPRETATION OF THE ECOFEMINISM IN THE GRAPES OF WRATH}

John Steinbeck points out that people should understand and respect the laws of nature, because the fate of human beings and the nature are closely linked. Steinbeck also believes that people are equal and interdependent, and he stresses that people should live in harmony to achieve interpersonal balance. In the novel, the land ravaged by sand and dust is just like the heroine Rose of Sharon who suffers from misfortune. One is the low yield, the other is the abortion. The author expresses his views on the connection between the plunder of nature and the oppression of women. The author condemns ecological problems and all oppression for the woman and advocates a new relationship of harmonious coexistence between people and between people and nature.

\subsection{Nature}

Ecofeminism points out that the main power structure of the western culture is the hierarchy of the patriarchal system. In this system, nature is regarded as the object of conquest and utilization, as well as a tool for servicing person. And slavery and destruction of nature will inevitably lead to the imbalance of the whole ecosystem.

\subsubsection{Influence of Industrial Civilization on Nature}

"Ecofeminism holds that the scientific model of the West and the Industrial Civilization are Patriarchal, anti-natural and colonial." [2] Industrial civilization oppresses and conquers the nature to meet the demands of human beings. Steinbeck strongly criticizes the thinking mode of patriarchal binary and the logic of domination by describing the farmers who are forced to leave their homes, as well as revealing the cause of ecological disaster and social crisis. At the beginning of the novel, Tom Joad was a representative of the poor farmers who were driven out of the generations of farming land by industrial civilization, the progress of science and technology "tractor". In Steinbeck's novel, industrial civilization is responsible for the nature disaster and suffering of human beings. Tractors is a "great crawlers moving like insects, having the incredible strength of insects", it will drive the farmers out of their homes for generations to live, and "They ignored hills and gulches, water courses, fences, houses". $[3,37]$ Large scale mechanized production swallowed the land which people depend on for existence, and cut off the link between man and land.

\subsubsection{The Relationship between Man and Nature}

In the travel notes Travels with Charley: In Search of America, John Steinbeck writes: "if the most versatile form of life, man, use the same way as they used to exist, they will not only destroy themselves, but also ruin other life." [4] There is such a profound meaning in the novel; for example, Joads sold all the thing that they had, moving from Oklahoma to the dream land-California. However, when they just start, "a big swift car whisked near, tires squealed. The dog dodged helplessly, and with a shriek, cut off in the middle, went under the wheels. The big car slowed for a moment and faces looked back, and then it gathered greater speed and disappeared. And the dog, a blot of blood and tangled, burst intestines, kicked slowly in the road." [3, 135] In this scene, the dog is a symbol of nature, it is crushed under the wheels rolling by the car, which is a symbol of the industrial civilization, and it implies that human civilization has kind of cruel nature.

People lack the respect to land and nature, ironically, their predatory development of land make them fall into poverty. "The owner men sat in the cars and explained. You know the land is poor. You've scrabbled at it long enough, God knows." [3, 34] Under the attack by the mechanical civilization, a large number of local farmers had to get out to flee. Just like the Muley, he once said 'I'm lookin' after things so when all the folks come back it'll be all right.' But I knowed that wan't true. There ain't nothin' to look after. The folks ain't never comin' back. I'm jus' wanderin' aroun' like a damn ol' graveyard 
ghos'." [3, 53] The ecological feminist scholar Diamond and Orenstein had described the relationship between the man and nature, and they said our destiny was intertwined because human life was dependent on the earth. From the point of ecology, John Steinbeck ruthlessly critique for rooting in the patriarchal dualism and the ruling class system, embodying a basic tenet of eco-feminism: Man is sacred, and all things in nature are sacred. Human is a part of nature and lives with nature. "Now the wind grew strong and hard and it worked at the rain crust in the corn fields. Little by little the sky was darkened by the mixing dust, and the wind felt over the earth, loosened the dust, and carried it away" [3, 4] No matter what we do to nature the results will eventually be reflected in ourselves. Therefore, human beings should treat, cherish and respect equally to nature.

\subsection{Representative Figures of Ecofeminism}

Ecofeminism claims that the cultural thinking mode and system of the patriarchal system led to the ecological and social crisis. "Without liberating women and breaking the patriarchal system, the ecological balance and stability, as well as the harmonious development of human society cannot be achieved."[5] Therefore, women are always the focus of the Ecofeminism. it "challenges all relations of domination, its goal is not just to change who wield powers, but to transform the structure of power itself."[6]

Steinbeck keenly observes that if people really want to recover the reverence to land, humans must subvert the core values of the patriarchal cultural and value the nature system. Women will play an important role in the new force of social change, which will bring vitality to the American society in the crisis. Ma Joad and Rose of Sharon are shining with the glory of maternal love, they are a symbol of the natural earth, carrying the continuation of life and hope.

\subsubsection{Ma Joad}

As man and nature have been destroyed at this time, the patriarchal society has also been shaken. Women are the continuation of life, and women status has been highlighted at this moment. John Steinbeck shows the reader a great love of women. Steinbeck made such a meaningful arrangement: Ma Joad, one of the characters in the novel, whose name never appeared in the novel. (Joad is her husband's name).Ma Joad is a perfect woman under Steinbeck's pen, and she has all the good qualities that women have. Her first appearance is busy cooking for the whole family. In Tom's eyes, "Her hazel eyes seemed to have experienced all possible tragedy and to have mounted pain and suffering like steps into a high calm and a superhuman understanding. She seemed to know, to accept, to welcome her position, the citadel of the family, the strong place that could not be taken". $[3,77]$ She knows that she is the core of the family. Being Strong and happy, no matter what happened at home, she can do it well. She takes good care of her whole family. From the beginning they move to the west, she believes that a family must be together. In her mind, she believes they will get over everything as long as the family can be together. Unfortunately, grandma and grandpa's death break her initial desire; Noah's leave, Connie's departure, and Casy's death, which make her suffer a painful torment, but she still uses the great mother's love to care about the broken family, since she has always been hopeful about their future. It is Ma Joad's insistence and faith that make the broken family alive. Ma Joad's strong, loving, determination and kindness inspire everyone around her. She is kind and selfishless, "As far as 'kin,' we can't do nothin', not go to California or nothin'; but as far as 'will,' why, we'll do what we will. An' as far as 'will'-it's a long time our folks been here and east before, an' I never heerd tell of no Joads or no Hazletts, neither, ever refusin' food an' shelter or a lift on the road to anybody that asked. They have been mean Joads, but never that mean." $[3,107]$ When Tom complains about the thing that: "We take a beatin' all the time." "I know." Ma chuckled. "Maybe that makes us tough. Rich fellas come up an' they die, an' their kids ain't no good, an' they die out. But, Tom, we keep a-comin'. Don' you fret none, Tom. A different time's comin'." [3, 294] At this point, the concept of unity and harmony between people has been vividly approved.

\subsubsection{Rose of Sharon}

Rose of Sharon is a beautiful woman; she is not as helpful and kind as Ma Joad at the beginning. She had been living in her own world, being simple and selfish little girl, and she wanted to live in California to enjoy her own life. But in the plight of western move, her husband deserted her, so she hated this world, and complained that the life gave her injustice and suffering. For example, she blamed Tom when he killed the police without considering his safety. "That lady told me. She says what sin's gonna to do. She told me. What chance I got to have a nice baby? Connie's gone, and I ain't getting' good food. I ain' getting' milk." Her voice rose hysterically. "And now you kill a fella. What chance that baby got to get bore right? I know-gonna be a freak-a freak! I never did no dancing." [3, 412]But with the baby in the belly grew up day by day, under the comfort, encouragement and demonstration by Ma Joad, Rose of Sharon changed to a great mother from an innocent daughter. At the end of the novel, Steinbeck gave us a meaningful ending: On a rainy night, Joads stayed in a broken barn to take shelter from rain. There, they fond a dying man, Rose of Sharon, a mother who just lost her child, rescued a dying man with her own milk. At this time, Rose of Sharon assumed the role being similar to 
the Mother Ma Joad, which approves that Steinbeck's female characters are the embodiments of the maternity and harmony among people.

\subsection{Social Relationships}

What Steinbeck condemns about is not only the social system that oppresses nature and women, but also makes human being themselves selfish and numb. Industrialization not only breaks the balance of natural ecology in the countryside, but also makes the human being become a victim. There is a scene in the novel: A friend of the Joad's family, who drove the tractor, destroyed their homes and drove them out of their homes. The tractor driver once said: "Can't think of that. Got to think of my own kids. "[3: 39] And machine civilization also leads to the alienation of people, people become machine dependencies, the man who drives a tractor, just a part of the monster, is a sitting robot. They don't understand the land, they don't like the land, and they despise the land, even if themselves. In Oklahoma, industrial bankers ruthlessly exploited farmers. "But-you see, a bank or a company can't do that, because those creatures don't breathe air, don't eat side-meat. They breathe profits; they eat the interest on money." [3, 34]The local farmers become aggravated regardless of life and death when they arrived at dreamy California. "I ain't got a hell of a lot of respec' for 'em now," said Muley. "On'y kind a gover'ment we got that leans on us fellas is the 'safe margin a profit.' $[3,58]$. What a cruel life it is!

Casy once said "It's ever'body," he said. "Here's me that used to give all my fight against the devil 'cause I figgered the devil was the enemy. But they's somepin worse'n the devil got hold a country, an' it ain't gonna let go till it's chopped loose. [3, 134]. What does Casy say here is "somepin worse'n the devil" is the social system. To realize the equality and justice of the society, people need to free themselves from the shackles of system and construct the new ethics values.

Mutual assistance do exist among these poor people, which shows the harmony and love. On the way to the West, Ma Joad gave out their insufficient food to the chance acquaintance, the Wilsons, also hands out the stew to the strange children under the condition that the family could not fill the belly. Finally, when the Joad's car broke down, the Wilson family helped to repair it, The two families make concerted efforts to help each other, which reflects the desire for harmony between people.

Ma Joad once shared her idea about future. "Woman looks at it like that. We ain't gonna die out. People is goin' on-changin' a little, maybe, but goin' right on." [3, 443]" She truly understands the permanence of humanity and she firmly believes that life may change sometimes, but man will go on persistently. Casy gets a feeling in the wilderness: "There were the hills, an' there was me, an' we weren't separate no more. We were one thing. An' that one thing was holy." [3, 85].It means human beings can be harmoniously united and living, since we are a big family.

So how to deal with the relationship between human and living environment and the relationship between the two sexes is a question that should be considered in establishing a harmonious social relationship. Life in nature is dependent on mutual care, so that women and men play their social roles equally. Establishing the harmonious relationship between man and nature, man and man, so as to establish the harmonious world.

\section{CONCLUSION}

We should establish harmonious ecological and social relationships. People do not pay attention to nature; environmental problem is getting worse, so the consequences are embodied on the dead baby that Rose of Sharon bored. As Uncle John floated the child downstream, he told: "Go down an' tell 'em. Go down in the street an' rot an' tell 'em that way. That's the way you can talk. Don' even know if you was a boy or a girl. Ain't gonna find out. Go on down now, an' lay in the street. Maybe they'll know then." [3, 468] It shows the pain that people experienced by the destruction of nature and human beings. In The Grapes of Wrath, the contradictions and conflicts among the farmers, banks, migrant workers and police, in fact, are caused by the deterioration imbalance between the human being and environment. For a long time, humans think that they are the center of the universe, they are regarded as the source of all value, and they judge all things with their own interests. Material interests are the only standard to measure the relation between people and people. Reanalysis of this work from the perspective of Ecofeminism, we can find that the novel is far beyond the limits of time and ideology; it reflects the deep thinking of the common problems and difficulties faced by mankind, and concern for the human's future and destiny. His thought is of positive significance to strengthen the protection of ecological environment, refocus on women's rights and interests, and construct the harmonious concept.

\section{REFERENCES}

[1] Benson, Jackson J, The True Adventures of John Steinbeck, Writer [M]. New York: Viking Press. 1984, p. 376.

[2] Jin Li, Ecofeminism [J]. Foreign Literature, Beijing. 2004(5): p.59.

[3] John Steinbeck, The Grapes of Wrath [M]. Penguin Classics. 2000: p.4-468. 
[4] John Steinbeck, Travels with Charley: In Search of America [M]. New York: Viking Press.1962, p. 56.

[5] Zhang Lisheng, Qi Yunyan, Fan Cheng. An Interpretation of The Eco-Feminism in The Grapes of Wrath. [J]. Journal of Kunming Metallurgy College, Kun Ming. 2010, 26(2): p.106.

[6] Starhawk, Feminist, Earth-based Spiritually and Ecofeminism. Philadelphia: New Society Publishers. 1989, p. 86. 